\title{
Emotional and Behavioral Problems
}

\author{
Asterios Kokkos* \\ Frederick University, Greece
}

Submission: May 13, 2017; Published: May 25, 2017

*Corresponding author: Asterios Kokkos, Master of Special Education, Frederick University, Nicosia, Cyprus, , Greece, Tel: 6945598017; Email: asteris.kokkos@gmail.com

\section{Mini Review}

Behavioral difficulties are a complex and very serious issue as their manifestation is not only due to genetic and neurological factors but also to the interaction children have with the environment where they live. A child's problematic behavior may be associated with the "bad" family environment they live in as well as the bad relationships they have with their family. Whether there are no ties of love between parents and their children, or they neglect them, or they do not show appreciation and respect, or they abuse them, and generally they do not praise them or they do not pay attention to their skills, it is very likely that these children develop problematic behaviors because of the grief and sadness they feel. A problematic behavior can be displayed either in an aggressive or antisocial way or with depression and frustration. Both internal and external problem behavior include isolation from the community and a negative identity.

Firstly, a key asset for the teacher is to create a relationship of trust with the child, to stress their positive characteristics and emotional skills, to encourage them to have a good image and appreciation for themselves, to create cooperation and communication ties between the teacher and the child as well as between the classmates and the child with problematic behavior, so that children could feel that they do not have a negative identity, that they are no different from the other classmates and especially could avoid any exclusion and isolation may have. Furthermore, as behavioral difficulties are mainly due to the child's psychological and social background, the teacher should also play the role of a psychologist before deciding on the causes of problematic behavior and how to deal with it.

Also, the teacher should be in excellent cooperation, contact and communication with the child's family and be familiar with the living conditions and emotional relationships that the child has with their parents. Also, there must be advisory consultancy for parents, teachers and children, excellent cooperation and communication with special consultants and finally, psycho educational programs in the classroom. Finally, to conclude, behavioral difficulties require special attention concerning the way each pupil is assessed and dealt with, because the environmental effect on the child contributes to the manifestation of a problematic behavior. For this reason, there should be cooperation and communication among the teacher, special consultants and parents, aiming at achieving child's right psychosocial analysis and finding effective measures to deal with it.

\section{Behavioral Problems- How to Handle Them}

i. Creating a positive climate in the classroom with communication and cooperation between teacher and students

ii. Promoting and enhancing child's emotional skills

iii. Cooperation between parents and school

iv. Behavioral control

v. Rules in the classroom

vi. Adults or experts in the classrooms as guides or child consultants

vii. Personalized intervention- teacher should devote time to the child to learn the special characteristics

viii. Students' positive initiatives and use of humour and alternative teaching methods

ix. Positive identification of evidence of problematic behavior

\section{The right functions of a school}

i. Positive climate

ii. Courses should be clearly presented 
iii. More time to students

iv. More opportunities for their goals

v. Use of psychosocial activities such as theatrical game and teams with communication and cooperation with adults or peers

vi. Contact with the family and special consultants concerning child's interests

vii. Children's skills should be taken into account

viii. Interpersonal relationships should be taught

\section{Teacher's attitude}

i. Facing children as a whole, not focusing on their problematic behaviors

ii. Cooperation with parents and consultants- information about dangers, participation, lack of stereotypes and aggressive behaviors
iii. Acting as a psychologist
iv. Being prestigious
v. Punishment not for revenge
vi. No preaching
vii. Neither rush nor delay in addressing a psychologist
viii. Knowing their characters and psychology
ix. Not hasty conclusions for an aggressive behavior
x. Teacher's cooperation with experts and consultants

\section{Interventions in the classroom}

i. Imbuing confidence in the teacher, boosting their ego and skills

ii. Acceptance by classmates and peers

iii. Creation of new social models

iv. Avoiding a negative identity

v. Factors leading to aggressive behavior

vi. Biological and psychological factors

vii. Family environment

viii. Social environment

ix. Low psycho-emotional and psychosocial development

X. Low self-esteem

xi. Rejection

xii. Poor skills in school

\section{Child's characteristics}

i. Low self- esteem
ii. Selfishness
iii. Lack of empathy
iv. Anger
v. Fear and stress
vi. Low performance
vii. Poor social relations
viii. Isolation
ix. Language disorders
x. Poor confidence
xi. They do not learn from their mistakes
xii. Lack of cooperation

\section{Factors leading to isolation}

i. Disagreeable climate

ii. Emotional rejection by teachers and classmates

iii. Victimization

iv. Negative cooperation with parents

v. Not identifying pshychological problems

vi. Lack of political integration

\section{Dealing with a problematic behavior}

A behavioral approach:

i. Positive support ( praise -points- applause )

ii. Temporary restiction to a desk to think and stay calm

iii. Symbolic rewards (the proper behavior will be rewarded using budges- when collecting 5 budges, a book from the library will be given

iv. Behavior contract ( self- control, negotiation , trust , realizable terms )

\section{Ecosystemic approach}

It is affected by the environment- mainly by the teacher so teacher's behavior should change in order to achieve student's desirable behavior:

i. Reframing (a new interpretation framework of the problematic behavior by the teacher)

ii. Incentive connotation ( the positive elements are presented forcing children to show the right thing)

\section{Active hearing}

Discussion aiming at learning the reasons as well as the way of thinking for the actions:

i. Positive functions (if you do not participate, I will focus on the other children) 
ii. The trap- door technique (it stresses the positive elements of a personality so that the problematic behavior will change)

iii. Mirroring (repeating some sentences in order to identify which emotions they cause) iv. Reflection (students' emotions are interpreted by their words).

Your next submission with Juniper Publishers will reach you the below assets

- Quality Editorial service

- Swift Peer Review

- Reprints availability

- E-prints Service

- Manuscript Podcast for convenient understanding

- Global attainment for your research

- Manuscript accessibility in different formats ( Pdf, E-pub, Full Text, Audio)

- Unceasing customer service

Track the below URL for one-step submission https://juniperpublishers.com/online-submission.php 
